\title{
On Characteristic Music Teaching in Kindergartens with National Music
}

\author{
Xiaoxiao Fan \\ Chongqing University of Education, Chongqing, 400000, China
}

Keywords: national music; kindergarten; characteristic music; teaching.

\begin{abstract}
As quality-oriented education reform goes on, there is a new change in the idea of preschool education. In terms of education form, people tend to start from children's physiological and psychological development rules, introduce national music appreciation and focus on characteristic music education to explore a feasible education mode for children. Kindergartens should combine their actual conditions to explore characteristic music teaching resources, take national music as the entry point, continuously deepen education reform and drive joint development of children and teachers. This paper states the necessity of implementing characteristic national music teaching in kindergartens, discusses the basic principles of introducing national music teaching in kindergartens, and interprets several countermeasures to carry out characteristic music course teaching by applying national music in kindergartens.
\end{abstract}

\section{Introduction}

In various teaching activities of kindergartens, children like music activity most so that teachers may integrate music activity in preschool education. According to relevant research, music education can not just promote healthy physical and psychological development of children, but also contribute to driving their all-round development of morality, intelligence and physique. Music education has become an important part of quality-oriented education for children. For a country with multiple nationalities, national music culture is always the important content of music education. Music education can not just promote inheritance and development of Chinese excellent traditional national culture, but also is an important way for children to understand national culture and enhance the sense of national pride. The integration of national music in characteristic music course can not only further enrich children's music skills and expand their view, but also let them feel rich knowledge in music and impart extensive and profound traditional culture to children more vividly.

\section{Necessity of implementing characteristic national music course teaching in kindergartens}

National music teaching is a content of characteristic music course teaching in kindergartens. It can not merely develop children' intelligence and thinking ability, but also enhance their aesthetic judgment. However, since popular music is always filled in the life of modern people, children also contact popular music. They know little about national music. If things continue this way, Chinese national music will be faced with the crisis of being neglected by the next generation. In fact, some kindergartens start to focus on the introduction of national music in schools, and explore implementation of characteristic national music teaching activity in kindergartens to let children feel the essence of Chinese culture and let national music which is faced with loss risk regain the nature of art. National music is an important inheritance content of national culture and owns great value. National music education should be implemented from the preschool period to let children have an understanding of national language and national traditions, cultivate their strong interest in national music, expand their view and knowledge scope and well drive the development of national culture. Kindergartens should overall apply multimedia equipment to play national music and dances. In this way, kindergarten teaching can develop to diversified directions, and children can be satisfied in multiple aspects such as singing, dancing and performance. This can greatly promote the expansion of national music education. 


\section{Basic principles of introducing national music teaching in kindergartens}

Firstly, the principle of national property. Children love in the actual social culture situation, and their cognition development decides their very high sensitivity to the things they experience. National music is usually an important content of cultural environment where children live, so it may be deemed as an educational resource. This completely conforms to children's development rules and features. More importantly, national music can undertake the significant responsibility of inheriting culture of each nationality, the national spirit and emotion of national music are difficult to be replaced by other art forms. In the historical development, people of each nationality sinfully make the particular musical instruments of nationalities and create characteristic songs on the basis of their life experience and aesthetic orientation. Both the tune and expression form own good lingering charm, which plays a very important role in driving children to master the content of national culture.

Secondly, principle of interestingness. National music comes from people's life, and is closely related to children's life. To practically meet children's needs, the principle of interestingness should be applied during choosing corresponding national music resources. In other words, the art image expressed by the selected music works should be bright and vivid, and the contents depicted should be the things children are familiar with. This can trigger children's emotional resonance, simulate their strong curiosity and give play to their rich imagination. For example, some songs of minorities show children's game scenes such as gamecock and mountaineering. The application of such interesting music materials approaching children's life in kindergartens' characteristic music education can no just let children get pleasant physical and psychological experience, but also let them enjoy the good atmosphere of games and improve their learning effect.

Thirdly, principle of education. Aesthetic education in preschool period is very important for children's health. Hospitable and enthusiastic characters as well as traditional etiquettes and habits of each nationality are embodied in national music. In addition, children like to imitate adults' behaviors in music, and overall show rich emotions such as pleasure, anger, sorrow and joy. Therefore, national music, game and dance may be applied to guide children, which is also an important content of aesthetic education for children. Such national music containing fine emotions can cultivate children's moral sentiments and beautify their souls.

\section{Several countermeasures to implement characteristic music course teaching in kindergartens by national music}

Firstly, create good music atmosphere and mobilize children's subjective initiative. National music teaching content should be set in kindergartens. The teaching materials should be suitable for children. Besides, kindergartens also need to organize multiple kinds of national music appreciation activities which should be open to the parents, and display all kinds of national musical instruments in the classroom. In this way, children can know features of the musical instruments, which can better help children to feel the important functions of the above musical instruments in national music. The multimedia equipment may be used to play the songs and especially national music that children are interested in. it is required to combine children's practical thinking features and apply the pictures to feel the meaning expressed in the music. Based on the implementation of the above activities, children can know children's mastery of national music. This is also very beneficial to the families to carry out national music appreciation. As kindergartens change the teaching mode, it is also required to consciously cultivate children's music talent, and mine their music potential, which is very good for improving children's language expression ability and enhancing national music appreciation ability. This innovative teaching method is different from traditional teaching mode. For music teaching of children, this is a new breakthrough. The author found in teaching practice that, children generally like characteristic music course teaching very much. As they learn deeply, they will generate the keen interest in national music. This is very beneficial to their future growth and study.

Secondly, apply music appreciation activity to motivate children's learning interest and make them understand the essence of traditional culture more comprehensively. Music appreciation is also an 
important content of characteristic music course teaching for children. The implementation of this link plays a great role in improving children's musicality and sensibility, expanding their music appreciation view and enhancing their music accomplishment. Every piece of music contains very rich national culture. Because of age feature of children, they cannot apply texts to understand the culture of a nationality, but music appreciation teaching can break through the limitation and let children experience music mood and content when appreciating music works of minorities. This can let children understand minorities and appreciate the beauty of music works from the music perspective. For instance, when letting children appreciate Dance of the Yao People in characteristic music course, the teacher may play the video of singing and dancing by Yao people to make them understand the life of minorities. The video content should be integrated with the structure, tune and situation of music so as to better help children be familiar with melody of national music and help them feel wonderful music mage and more vividly master the knowledge of costume, musical instruments and customs of Yao people.

Thirdly, apply rhythm and dance to improve children's music skills. Children's rhythm mainly refers to implementation of various imitation actions according to music nature. For example, children may be asked to imitate grape picking in Uigurian dance, horse riding and milking in dance of Mongol nationality, and bending and stooping in the Tibetan dance, etc. Dance is a comprehensive performance art form which embodies human thought and emotion through body movement and modeling. For children, too complicated and difficult actions will beyond their scope of comprehension, naturally leading to their averse emotion. So, it is required to teach children the basic and simple national dance movements in accordance with their features. In this way, they can understand and grasp dance steps and dance movements soon as well as express their emotions by following the music. Promoting children's rhythm sensation development is an important link of improving their music identification ability, while rhythm is a very important factor in music. Hence, in order to further develop children's music skills, it is very important to enhance rhythm sensation cultivation. Rhythm and dance own very important value in cultivation of children's rhythm sensation. To drive cultivation of children's rhythm sensation, more opportunities should be provided for children. Rhythm and dance can exactly show these body movements. The differences of music can be shown through the sound, speed and intensity in the music, so it is very necessary to enhance rhythm and dance training.

Fourthly, rationally apply national music materials to integrate game teaching content. Characteristic music teaching form for children should be rich and colorful. The emphases of different teaching modes are different, and they also have diverse functions for the development of children's music ability. Thus, teachers need to properly process music materials so as to form different forms of music activities and drive sustainable development of children's music ability. Teachers may adapt music materials into the songs and dance music, and continuously improve children's music feeling and expression ability through music appreciation, song teaching and rhythm music, etc. The game is the favorite characteristic activity of children. To achieve gamification of characteristic music course teaching, games need to be applied to implement music education for children, improve their music accomplishment and individuality in the relaxing and pleasant game atmosphere. When implementing characteristic national music teaching, kindergartens should strive to teach through lively activities. For example, children may appreciate song and dance Ban Deng Long of Zhuang nationality, and Wu Jin Shi of Han nationality. These songs are adapted according to psychical games of each nationality. There are game contents such as stool vaudeville of Zhuang nationality and lion dance of Han nationality, and they are very interesting. If children participate in the song and dance performance, their physical quality can well improve. First of all, children should practically experience dragon dance and lion dance. Then, children can gradually learn to sing these songs when playing. Next, teachers may guide them to perform according to the lyrics. This can not just improve children's performance action harmony, but also further enhance their comprehension of national music. 


\section{Conclusion}

In conclusion, the suitable learning contents and teaching methods should be chosen for characteristic music course teaching in kindergartens. Meanwhile, the proper education environment should be created to drive children to appreciate national music actively so as to enhance their music appreciation ability. This is also very beneficial to children to gain the experience and enjoyment of beauty and get harmony and unity between aesthetic taste and national music art. Promoting national music level of music teachers can let characteristic music course atmosphere become stronger. National music enlightenment can let children better show their music strength and talent and further develop their thinking ability so as to exert the greater value for inheriting excellent Chinese traditional national culture.

\section{Acknowledgement}

Topic level: 2017 university-level scientific research project and general annual project of Chongqing University of Education; Project title: Development and Application of Characteristic Music Course Resources of Kindergartens in Tujia Nationality of Chongqing under Overall Urban and Rural Development, Project No.: KY201713B.

\section{References}

[1] Xu Zhuoya, Kong Qiying, Guide Books of Penetration Course Implementation in Kindergartens (Art), Nanjing: Nanjing Normal University Press, 2007.

[2] Zhao Quansheng, Practical Exploration of Development and Application of Local Music Course Resources, Journal of Dali University, 2007 (3).

[3] Zhou Suzhen, Analysis on Implantation of Mongolian Folk Song Education Activity - Case Study of Mongolian Kindergartens in Hohhot City, Journal of Inner Mongolia Normal University (Philosophy and Social Science), 2009 (2).

[4] Yang Xiao, Penetration of National Folk Music in Children's Music education, Naitonal Music, 2010, (5). 